\title{
Religious Education in Greece Under the Scope of Interculturalism
}

\author{
Evanthia Tsaliki (Corresponding Author) \\ International Centre for Intercultural Studies, UCL Institute of Education, University of \\ London \\ Email: inka140@hotmail.com/evanthia.tsaliki@ucl.ac.uk
}

Received: August 25, 2016

doi:10.5296/jet.v4i1.9923
Accepted: September 29, $2016 \quad$ Published: February 6, 2017

URL: http://dx.doi.org/10.5296/jet.v4i1.9923

\begin{abstract}
The aim of this presentation is to provide an overview of the subject of Religious Education (RE) taught in Greek primary and secondary schools through the lens of the diversity existing in the Greek society. The presentation refers to the Christian Orthodox oriented content - and the roots of this orientation - of the school textbooks and the curriculum on the subject of Religious Education related and compared with the Greek legislation and the European guidelines on Religious Education in detail. The issue was explored through the phenomenological approach which illuminates the subject of RE taught in Greek schools via the method of document analysis. The document analysis showed that the Greek legislation and the curricula of RE seem to be by and large consistent with the European guidelines on the freedom of religious conscience, as this is preserved in some way. However, neither the development of inter-religious dialogue nor the encouragement of pupils to discover different religions is foreseen within school with the exemption of some lessons relevant to other religions and faiths less in primary school and high school and more in Lyceum, the attendance of which is optional. In the end, the findings are discussed and some thoughts are expressed regarding the dimension that the subject of Religious Education should take in future in view of the present composition of the population in Greece.
\end{abstract}

Keywords: religious education, intercultural education, curriculum, legislation, Greece

\section{European Guidelines on Religious Education}

Article 9 of the latest version of the European Convention on Human Rights (2010) among others recognizes the freedom of religion without however a clear definition of the conditions of religious freedom due to the lack of consensus on issues of religion across the member states. Therefore, the White Paper on Intercultural Dialogue (2008) stresses the importance and the need for the development of intercultural dialogue between the religious communities and the public authorities as well as between the religious communities (interreligious dialogue) themselves so as they can contribute to a deeper understanding between different cultures. The 
need for dialogue between religions was also stressed two years before in 2005 in the Recommendation 1720/2005 of the Parliamentary Assembly about Education and Religion.

In the same document the role which family, social media and the school plays in the formation of one's religious identity is recognized with a detailed reference to the aims that the subject of religious studies should fulfill in the school. More specifically, according to the Recommendation religious studies should be taught in such a way so as to encourage pupils to discover the different religions and to respect everyone's right to believe in a religion or the right of not having a religion. The importance of teachers' specific training on religious studies is also emphasized. The role of the school system in the instruction of religious studies is further and in more details explained in the Toledo Guiding principles (2007) on teaching about religions and beliefs in public schools. Particular reference is made to the objectives included in the school curricula designed for teaching about religions and beliefs and the evaluation of their objectives as to whether they promote the right of free religious conscience, present different religions and beliefs and connect these religions and beliefs with global, social and local issues without undermining the role of families and religious communities towards this aim. Teachers' specific training on religious studies is also imperative according to the Toledo Guiding Principles (2007) which is based on two main principles; on the one hand on the positive value that the respect for everyone's right to freedom of religion and belief has and on the other hand on the idea that teaching about religions and beliefs can reduce harmful misunderstandings and stereotypes.

Another important issue brought into the fore both in the White Paper on Intercultural Dialogue (2008) and the Recommendation of the Parliamentary Assembly (2005) is the neutral role that the Council of Europe and the state need to retain towards the exercise of various religions, faiths and beliefs as well as the separation between politics and religion.

Finally, all the aforementioned documents produced by the Council of Europe and organisations affiliated to it underline that if the subject of religious studies incorporates the study of various religions, beliefs and faiths through intercultural dialogue, misunderstandings, stereotypes, fanaticism, extremism and terrorism will be reduced, tolerance and respect will be developed (Zambeta, 2008). Nevertheless it is not claimed that intercultural dialogue constitutes a panacea to the resolution of the issues raised above and at the same time it is recognized that there are countries where there is a state religion and the school focuses on this religion, as it is also stated in the Recommendation CM/Rec (2008) 12 on the Dimension of Religions and Non-Religious Convictions within Intercultural education (https://wcd.coe.int/ViewDoc.jsp?id=1386911\&Site=CM).

\section{The Case of Greece}

In this section the legal framework and the educational legislation regarding Religious Education (RE) will be presented and discussed. An attempt will be made to investigate the connection of this legal framework with the curricula and the textbooks on RE as well as with the European guidelines on RE in order to see if and to what extent there is agreement or disagreement between these three spheres followed by a discussion. 
At this point it should be noted that there is a 4.7 percentage of Muslims living in Greece (http://www.iefimerida.gr/news/186711/oi-moysoylmanoi-tis-eyropis-posoi-einai-poy-zoyn-h artis) and 74 Christian denominations and other Christian groups existent in the country according to the Church of Greece (http://www.ecclesia.gr/greek/holysynod/commitees/ heresies/omades_christ.html).

\subsection{A Description of the Greek Educational System}

According to the Greek educational system education is compulsory for nine years and it is provided for all children in primary schools for six years from the age of six and then for three years in High school (Gymnasium). After the nine years of compulsory education one can continue education for three more years in Upper High School (Lyceum) or in a vocational Lyceum. During the 12 years of education (six-year primary school, three-year Gymnasium, three-year Lyceum) the module of Religious Education is compulsory and it is taught two hours per week every year except Y3 of Lyceum in which it is taught one hour per week and the three years of the vocational Lyceum in which it is taught one hour per week during the first and the second year (http://www.minedu.gov.gr/thriskeymata-main/ ekklisiastika-sxoleia-main/249-sxoleia-ekklisiastikis-ekpaideysis.html).

In primary education the subject of RE is taught by primary school teachers who have been graduated from the Departments of Primary Education of the Greek Universities and have been trained in teaching the subjects of Greek Language and Literature, History, Geography, Citizenship Education, RE, Mathematics and Physics. Whereas in secondary education the secondary school teachers teach a specific subject on which they have been trained in the respective department of the University. Thus, as far as RE secondary school teachers is concerned they have been trained in the Orthodox Theological Departments of the Greek Universities and the courses they take include sociology and history of religion, teaching religions, religion and culture, etc. (Karamouzis, 2014).

There are also seven ecclesiastical high schools (Gymnasium) and nine upper high schools (Lyceum) in which pupils need to submit a separate application so as they can be accepted and enrolled accompanied with pupil's $\mathrm{CV}$ and a reference from the local Archbishop (http://edu.klimaka.gr/leitoyrgia-sxoleivn/ekklhsiastika/2423-eggrafes-ekklhsiastika-sxoleia.h tml).

\subsection{The Legal Framework and the Educational Legislation in Relation to Religious Education}

According to Article 3, paragraph 1 of the Greek Constitution (http://www.hellenicparliament.gr/UserFiles/f3c70a23-7696-49db-9148-f24dce6a27c8/SYNT AGMA1_1.pdf) the dominant religion in Greece is the religion of the Eastern Orthodox Church. It recognizes Jesus Christ as its head and it is autocephalous. The State and the Church are not separate but they have distinct roles (Efstathiou et al., 2008). In the same document according to two paragraphs of the Article 16 referring to education, art and science the academic freedom and the freedom of instruction must be in accordance with obedience to the Constitution. 
However, the aforementioned points are controversial with Article 13 of the Greek Constitution which demonstrates that the freedom of religious conscience cannot be violated, that every know religion is free to be practiced, that its worship can be practiced with no obstacles under the protection of laws and that proselytization is forbidden.

The content of Law 1566/1985 (http://www.pi-schools.gr/preschool_education/nomothesia/ 1566_85.pdf) referring to the structure and the operation of primary and secondary education is in the same spirit. More specifically, in the first paragraph of Article 1 it is stated that the aim of education is among others to help pupils have belief in the authentic elements of the Christian Orthodox tradition while at the same time it is recognized that the freedom of religious conscience cannot be violated.

It seems as if the parts of the Greek Constitution as well as the parts of Law 1566/1985 referring to the issue of religion are in agreement. In both texts it is recognized that the dominant religion is the Christian orthodox religion and that Greek education aims at encouraging pupils to believe in it while it is claimed that pupils' religious conscience cannot be violated.

Circular 12773/A2/23-01-2015 (http://edu.klimaka.gr/leitoyrgia-sxoleivn/anakoinvseis/884 -apallagh-apo-to-mathhma-twn-thrhskevtikwn.html) aims at preserving the freedom of pupils' conscience by proving the right to pupils who are not Christian Orthodox to apply in order to be exempted from the subject of Religious Education. Pupils' parents or guardians - when pupils are under eighteen years old - are responsible of completing this application and it is not necessary for their religion to be stated in the form.

The very same act of providing the pupils with the right to be exempted from the RE subject lead us to the thought that not enough space is provided within the instruction of RE in Greek schools for pupils who are not Christian Orthodox to learn more on their religious faith or express their views in case they are atheists, that is the RE subject is mainly focused in the Christian Orthodox religion and tradition, as the analysis of the content of the curricula and the school textbooks will show below (Karamouzis, 2014).

\subsection{Curricula and Textbooks}

According to the Greek educational system there is a school textbook for every subject taught both in the primary and secondary school level (Gymnasium and Lyceum). These textbooks are written and published under the aegis of the Ministry of Education and are accompanied with a Teacher's guide book which includes the objectives of each unit with its lessons as well as guidelines on how the lesson could be taught. The instruction of each subject is based and guided by the textbooks, the Teacher's guide book, the general curriculum (namely cross-thematic/interdisciplinary curriculum) and the curriculum for each taught subject separately. The aims and objectives in the curriculum of each subject are in alliance with the general cross-thematic curriculum and this is depicted in the content of the school textbooks. However, teachers have the freedom to make a critical selection of the objectives of each unit and its lesson (Koukounaras - Liagkis, 2014). They also have the freedom to decide on the units and the lessons of each unit they would find more appropriate to teach as well as the 
activities and the homework they would prefer to assign to the pupils in order to fulfill the objectives and the aims of the lesson.

The same pattern applies in the subject of RE both in primary and secondary education. There is a school textbook accompanied with a Teacher's guide book the content of which seems to be in agreement with the aims of the general cross-thematic curriculum as well as the curriculum on RE for each one of the four years of primary education and the three years of secondary education (Gymnasium and Lyceum).

To begin with, in primary schools RE is taught in the last four years of the school to pupils aged from 8 to 12 years old. In the first two years of primary school (pupils aged from 6 to 8 years old) there is no RE provided according to the timetable. However, there is a reference to Christmas time and Easter customs as part of the culture of the place pupils live in within the framework of the taught subject titled 'Studying the Environment' in Y1. In Gymnasium $\mathrm{RE}$ is taught across the three years of attendance and there is a different school textbook for each year and the same applies to Lyceum.

\subsection{Cross-Thematic Curriculum and Curriculum on Religious Education}

In the general part of the cross-thematic curriculum (2003) when reference is made to the reinforcement of the cultural and linguistic identity of pupils within the framework of a multicultural society it is underlined that it is necessary for each person to learn to live with the others respecting their culture and their language. At the same time it is demonstrated that the national and cultural identity needs to be preserved through the development of a national, cultural, linguistic and religious education and that this position is also supported by all member states of the European union, as it is stated in the Recommendation CM/Rec (2008) 12 on the Dimension of Religions and Non-Religious Convictions within Intercultural education indeed.

In view of this thesis, it seems that there is an analogy between cross-thematic curriculum and the content of the curriculum on the subject of RE for compulsory education (Primary school and Gymnasium). More specifically, if one reads thoroughly the aims of RE included in the curriculum of the specific subject, it is apparent that the emphasis is on the knowledge of the Christian belief, the Christian orthodox tradition, its relation to history and its role in the formation of the Greek and European culture. Nevertheless, there is some space dedicated to the development of critical elaboration of different religious principles and attitudes, the respect of one's special characteristics and religions as well as the need for the development of inter- Christian and inter-religious communication. The need for inter-religious dialogue is also mentioned in the Recommendation 1720/(2005) of the Parliamentary Assembly about Education and Religion.

At this point it should be mentioned that an effort was made on behalf of the Greek state to make reforms on the existing curriculum by introducing in 2011 a pilot scheme titled 'New School' which is still implemented in particular schools (21 preschools, 99 primary schools and 68 secondary schools) all over Greece. According to this pilot scheme the subject of RE escapes the narrow boundaries of theology by providing freedom to teachers to design their 
own syllabus aiming at developing critical understanding, respect and dialogue between pupils of different religious backgrounds. However, as Koukounaras-Liagkis (2014) denotes even within the framework of this new scheme the study of world religions is estimated at $10 \%$ of the whole RE curriculum and the curriculum has managed to move from mere catechism to a mild confessional education.

In the reports produced after an evaluation of the implementation of the pilot scheme primary school teachers mention that they faced difficulties in teaching the specific subject due to their lack of special training in issues of RE as well as due to the absence of specific school textbook. Similarly, secondary school teachers found it difficult to design their own syllabus, though they support the view that the incorporation of epistemological elements and the pedagogical approach in the RE subject was imperative. This view may be formulated by the fact that they have received special training on RE, as they are graduates of the Greek University Departments of Theology (Koukounaras - Liagkis, 2014).

The aforementioned scheme is still in an experiential stage. Therefore, in this presentation the situation existing in the majority of the Greek primary and secondary schools regarding RE in terms of the curriculum and the school textbooks will be presented, analysed and discussed.

\subsection{Primary and Secondary Education School Textbooks}

In turn, the units included in the school textbooks for every year in primary school and in Gymnasium serve the aims set both in the cross-thematic curriculum and in the curriculum of the subject of RE with stress on the Christian orthodox religion, its symbols, the life of various saints, the life of Jesus Christ as well as the ecclesiastical art. In the school textbook of Y5 (10-11 years old/primary education) in some lessons the protection of the environment, the preservation of peace in the world as well as the protection of human and children's rights are presented. However, these issues are discussed though the lens of the Christian orthodox religion. In addition, in Y6 (primary education) four of the lessons of the book refer to the Orthodox in other countries, the Roman Catholic, the Protestants, the worship of the Jews in the synagogue and the prayer of the Muslims in the Mosque (http://ebooks.edu.gr/new/ allmaterial.php) ${ }^{1}$. At this point it should be noted that pupils in primary school have also the chance to get know the Christian Orthodox religion in the subject of History in Y5 and Y6 as this is inter-wined with the Byzantine era and culture and with the Greek rebellion of 1821 against the Turks (Mousiadou, 2014; Tsekou, 2015). Moreover, in the textbooks of the Greek language across all years of primary school there is a unit dedicated to Christmas and Easter. Through literary texts and poems pupils may get to know more on those religious events and their tradition in the Greek society ${ }^{2}$.

Similarly, in the textbooks in Gymnasium (secondary education) the focus is also on the

\footnotetext{
${ }^{1}$ According to research undertaken by Tsekou (2015) in the secondary school textbooks of RE (Gymnasium and Lyceum) people coming from the Balkans are presented as if they belong to the 'family' of Orthodoxy. This policy seems that it is adopted in order to assimilate in the Greek society those people who come from these countries and work in Greece in an effort to preserve social coherence and peaceful co-existence under the cloak of the 'same faith'.

${ }^{2}$ However, there are texts with an intercultural and inter-religious dimension. For example, in the Y5 primary school textbook of Greek Language there is a literary text - included in the chapter of Easter time - which narrates the story of a Greek Christian Orthodox woman and a Turkish Muslim woman who celebrated together the different events of their religions; Easter and Ramadan respectively.
} 
Christian Orthodox religion with the study of the Old and New Testament as well as the life and work of Jesus Christ. Only in Y3 (14-15 years old) one lesson refers to Roman Catholics, another to Protestants and in another lesson the issue of sects is elaborated (http://ebooks.edu.gr/new/allmaterial.php). The aforementioned lessons constitute the only references to other religions throughout compulsory education. At this point it should be reminded, as stated above, that it is within teachers' discretion to decide whether or not they will teach these lessons referring to the other religions or not. Additionally, in the textbooks of Greek Literature of Y1 and Y2 there is a unit which includes literary texts relevant to the Christian orthodox religious life (http://ebooks.edu.gr/new/allmaterial.php).

In the textbooks of Lyceum - which is included in the category of optional education - more space is devoted to the presentation of other religions. For example, in Y2 (16-17 years old) of Lyceum there is a whole unit referring to the Ancient Greek religion, the African religions, Islam, Hinduism, Budism, Yoga ${ }^{3}$, the Japanese religion and the Chinese religion. This unit offers the chance for the development of inter-religious dialogue, as stated in the curriculum. In each lesson of the unit a different religion is presented including pictures with religious symbols and rituals, texts-sources derived from the relevant religion as well as questions for pupils to reflect on this religion in relation to the other religions and on their basic principles. Furthermore, in Y3 (17-18 years old) of the Unified Lyceum religion is connected with the biological dimension of life, the problems of conscience and with crucial existential situations (stress, loneliness, immigration, unemployment, marginalization) (http://ebooks.edu.gr/new/allmaterial.php), that is RE lends itself to a more social dimension. However, as stated before, Lyceum constitutes optional education and if adolescents do not opt for it, they will not have any chance to get to know other religions at least in terms of schooling.

\subsection{Everyday Practice}

Teachers' everyday practice on religious education and on what actually is practiced and delivered in the classroom and the school within the framework of the hidden curriculum must seriously be taken into account. First of all, it is commonly accepted that teachers' lesson planning may be influenced by their professional beliefs on how RE can better be implemented as well as by their personal religious beliefs.

More specifically, in the case of Greece primary school teachers may have received training on RE during their undergraduate studies. However, the instruction of RE constitutes an optional module in the university syllabus. This is because the departments of primary education of various Universities in Greece retain autonomy to a certain extent on the modules included in their programme of study. Secondary school teachers working both in Gymnasium and Lyceum are trained in the Orthodox Theological departments of the Greek Universities (Karamouzis, 2014). Therefore, one would expect that they would have a more open-minded approach to the teaching of RE. However, it seems that in the case of theologians who have graduated from the Greek Departments of Theology and have been

\footnotetext{
3 Yoga means union and it constitutes a technique which is used in eastern religions such as Hinduism for the union of the humans with the divine elements inherent in them.
} 
trained in teaching RE in secondary education they are divided into two different groups according on their views on how RE should be taught in the schools. One group believes that the Christian Orthodox religion and tradition should be retained in its present dimension, while the other group believes that diversity can better be understood through the study of religions (Karamouzis, 2014)

As far as the operation of Greek primary school is concerned the role of the hidden curriculum must not be underestimated and overlooked. Hidden curriculum ${ }^{4}$ plays an important role and forms the type of education offered in each school. According to Apple (2004) the hidden curriculum refers to norms, behaviours and values which are implicitly taught in schools and are not included in the official curriculum. Dreeben (1969) argues that these norms, behaviours and values are learned by students unconsciously in the classroom and school life and shape the ongoing social, economic and political order. In view of this, the morning prayer in the school, the frequent visits of the pupils to the church in order to attend a service -which takes place in every primary and secondary school - the organization of celebrations related to religious events such as Christmas and Easter or the representation of various religious events such as a religious wedding and a baptism, the artefacts made for Christmas and Easter time - especially in kindergarten and primary school -, the icon of Jesus Christ hanged on almost every classroom - symbol related to the Christian orthodox religion - of the mainstream schools in Greece as well as teachers' possible religiosity inherent in their behavior addressed in the school may influence the message which is conveyed to the pupils regarding religious issues. They may also contribute to a certain extent in relation to the family and social media to the formation of their religious capital, as suggested by Karamouzis (2014).

Regarding secondary education the picture is almost the same regarding the hidden curriculum. The morning prayer, the religiosity of RE teachers and the pupils' visits to the Church to attend the service may play a role in formulating their views on religious education in combination with the family and the social media, as stated in the previous paragraph.

There may be instances indicating that pupils' different religions are respected, nonetheless, not against the Christian Orthodox religion as research revealed (Tsaliki, 2012) in the case of an intercultural primary school in northern Greece in which a party is organised every year in the school so that Muslim pupils can celebrate Eid5, one of the greatest celebrations of the Muslim religion. These events organised show that teachers take into account all pupils' cultural characteristics. However, one of the teachers strikes the right note by stating that an intercultural dimension needs to be present in all aspects of the school (Banks et al., 2001); that is, in all levels of school life the message that all cultures and languages are equal should be transmitted (Hopkins and Harris, 1997; Savvidou, 2005). She states that

\footnotetext{
4 According to Martin (1976) as cited in Gordon (1982) the hidden curriculum includes all norms, behaviours and values which are intended or unintended on the teachers' or school's behalf but are not acknowledged to the pupils.

5 The full name of the festival is Eid ul-Fitr. However, in the text the festival has been written Eid's, because it is better known by this name in Britain.
} 
'In the classroom, when we have time we talk about Ramadan. That means that we respect it at a personal level. However, when Muslim pupils are absent for this celebration we write down their absences. Moreover, in this school $80 \%$ of the pupils are Muslims. Nevertheless, they are obliged to listen to the traditional Christian Orthodox prayer every morning so that 10 Christian Orthodox pupils can pray'.

A research study conducted by Karamouzis (2014) among Greek student primary school teachers and Greek in-service primary school teachers showed that the student teachers believe that RE will need to change its content and purposes towards a more inter-religious perspective whereas the in-service teachers support the view that such a change is quite bold without specifying the reasons. Nonetheless, the vast majority of both groups said that they would make their own decisions on the content of RE they would have to teach. This finding reveals that teachers take the initiative to adapt the subject to the requirements of their class and the school in general. Although more than half of both groups described themselves as religious believers, the aforementioned finding indicates that the respondents' personal religious beliefs do not influence their decisions on the aims and the objectives they set for the subject of RE. This is also confirmed by both groups' belief that a subject oriented to interreligious education should be mandatory for all pupils including those being atheist or agnostic.

\section{Some Thoughts and Discussion on Religious Education in Greece in Relation to Intercultural Education}

As briefly stated in the abstract of the article the issue of Religious Education in Greece was explored through the phenomenological approach which illuminates the specific via the method of document analysis. More specifically, the document analysis was made in four different levels. First of all the European Guidelines on how Religious Education should be implemented were studied. At a second level the Greek legislation in relation to the role of the Christian Orthodox Church and the dominant religion in Greece and to the general aim of education in Greece was explored through the study of the relevant laws. The curriculum in Religious Education both in primary and secondary education was carefully read at a third level. At a fourth level the issues with which the school text books on Religious Education deal with were written down in categories. Then a comparison was made in three different stages: a comparison between the European guidelines and the Greek legislation regarding the issue, a comparison between the curriculum on RE and the actual school books and in the end a comparison of the actual school books and their spirit with the European guidelines which refer to inter-religious dialogue.

As the analysis above reveals it seems that the school textbooks on RE are written in such a way so as to fulfil the aims set in the cross-thematic curriculum and the curriculum of the subject of RE. In turn, the school textbooks and the curriculum on RE are in accordance with the Greek Constitution and the aim of education as set in Law 1566/1985 referring to the structure and the operation of primary and secondary education. 
More specifically, in Greece the dominant religion is the Christian Orthodox religion and Greek education aims at encouraging pupils to believe in it. The aims of the cross-thematic curriculum and the curriculum on RE moves towards the same direction and these aims are fulfilled through the units and the lessons they are included in the school textbooks. Thus, the school textbooks and the curriculum seem to be in accordance with the legislation. More specifically, as stated in previous sections, according to the Greek Constitution and the educational law it is recognized that the dominant religion is the Christian orthodox religion and that Greek education aims at encouraging pupils to believe in it. In turn, the cross-thematic curriculum and the curriculum on Religious Education emphasize the preservation of the national identity though the development of religious education which is practiced in the school text books as they include texts referring mainly to the Christian belief and the Christian Orthodox tradition.

Freedom of religious conscience and the respect of religious diversity are rights which are mentioned and protected both by the Greek Constitution and the educational legislation (Law 1566/1985). However, in terms of schooling these rights are protected only by the right provided to pupils to be exempted from the subject of RE. Within the school context and the subject of RE no further provision is made for pupils who are not Christian Orthodox to talk about their faith or their religion with the exemption of Muslim pupils in attending the Greek state schools. In this case according to Law 3536 of 2007 - which was amended in 2013 Muslim pupils will have the chance to attend Islamic RE lessons during the timetable of the school, since they have the right to withdraw from the official subject of RE offered in the schools. However, this is a regulation referring to Muslim pupils may be because in West Thrace, Greece the conditions are complicated and difficult to be interpreted and relate to policy matters (Koukounaras - Liagkis, 2013). However, what about the pupils who believe in other religions in other parts of Greece? What are the chances for them to express themselves through talking about and practicing their faith/religion within the school framework and what are their chances for their religious identity to be valued in the school?

At this point it should be noted that the Greek state through the cross-thematic curriculum takes precaution by mentioning that RE in school is supplementary and that it is also provided by the family and the Church. Thus, it recognizes that the contributing factors to the formation of a religious identity are not only school, but also the Church and the family. This position is also supported by the Greek Constitution by providing the right and freedom to people to practice their religion and its worship - as long as it does not offend the Greek state - in different aspects of their lives and not only in the school.

The Greek legislation and the curricula of RE seem to be by and large consistent with the European guidelines on the freedom of religious conscience, as this is preserved in some way. However, neither the development of inter-religious dialogue - as denoted in the White Paper on Intercultural Dialogue (2008) - nor the encouragement of pupils to discover different religions according to Recommendation 1720/(2005) is foreseen within school with the exemption of some lessons relevant to other religions and faiths -as it is claimed in Toledo Guiding principles on teaching about religions and beliefs in public schools (2007) - less in primary school and high school and more in Lyceum, the attendance of which is optional. 
The aforementioned findings make us think why and how it is possible for the subject of RE to be mainly orientated to one religion - that is the Christian Orthodox religion - when Greek society - being also part of a European multicultural setting- constitutes a multicultural society the diversity of which is reflected into school, as well. According to recent data for the school year 2014-2015 there were 74,834 foreign pupils, 3,180 repatriate pupils and 15,911 Roma pupils enrolled in primary and secondary education (Palaiologou \& Evaggelou, 2015). To the aforementioned data the number of the first refugee pupils enrolled in primary schools foe the school year 2016-2017 should be added. The diverse composition of the pupil population in Greek schools produces questions regarding the nature of education offered so as to meet the needs of this diverse pupil population taking into also account Law 2413/1996 referring to intercultural education the aim of which is is to provide education to young people with educational, social or cultural needs. There are 13 primary schools, 7 high schools (Gymnasium) and 4 upper high schools (Lyceum) designated as intercultural primary schools across Greece. However, they cannot meet the educational needs of all foreign and repatriate pupils of the region in which they are located. Therefore, these needs have to be met within the mainstream state schools.

It is obvious that the subject of RE in Greek mainstream schools does not deviate from its Christian Orthodox orientation (Zambeta, 2008) containing some references to other religions and faiths as well as some social problems which again are discussed through the Christian Orthodox dimension.

Undoubtedly, the intention of the Greek state is the development of the Christian Orthodox identity for its citizens which is thought as an integral part - together with the Greek language and the Greek history - of a national identity and the formation of a Greek-orthodox national collective conscience (Karamouzis, 2014; Tsekou, 2015). This thesis is also supported by the Church in Greece. Even in periods during which the Greek state made an effort to adopt a more flexible stance towards issues related to the Christian Orthodox religion (civil wedding, legitimization of abortion, divorce by mutual consent) they met the resistance of the Church and its persistence for the subject of RE to be compulsory in the school. Therefore, they withdrew from their initial position in the view of the risk of a political cost (Efstathiou et al., 2008; Karamouzis, 2014; Tsekou, 2015). It seems as though there is a two-way relationship between the Christian Orthodox Church and the Greek state (Bash, 2008).

Greece, among other European countries, considers itself monocultural, mainly for historical and social reasons (Frangoudaki and Dragonas, 2000). Greeks tend to focus on how they have influenced others by "drawing on the ancient "glorious past", as Traianou (2009) denotes, instead of examining at the same time to what extent they have been influenced and by whom (Broome, 1996). The need of Greeks to develop and maintain a national identity stems from the fact that it was not until 1831 that the Modern Greek state was established after the Turkish occupation from 1453 AC and for four centuries. According to Traianou (2009) more recent events, such as the large-scale immigration to Greece from countries of the former Communist Block, the conflict of Turkey over the occupation of Northern Cyprus in which people of Greek origin live and the constitutional name of FYROM (Former Yugoslavia Republic of Macedonia) strengthened Greeks' need to build a national identity in which the 
Christian Orthodox religion has a distinguishing position. It seems that Greeks feel threatened by their Balkan and Turkish neighbours. Therefore, they feel the need to differentiate themselves and reinforce their presence in Europe by developing a strong national identity (Persianis, 1978 as cited in Trainou, 2009) without being hostile to Europeanization and globalization parallel to that, as Efstathiou et al. (2008) points.

\section{Conclusions}

In Greece the role of the Church and the State are distinct. Nevertheless, the Church has managed to establish itself and express its views negatively or positively on decisions made by the current governments which may seem to connect with religious roots (divorce, abortion, marriage). It also expresses its view on the religiousness of the Greek society, on the content of the subject of RE taught, its orientation as well as on the necessity of the instruction of the Christian Orthodox religion for the preservation of the Greek national identity within the European and global context. The Christian Orthodox religion, the Greek culture and history as well as the Greek language are components of the Greek national identity the preservation of which has historical roots.

In a synopsis, the content of the RE curriculum and the school textbooks include mainly texts, ideals, ideas, values, historical events which connect with the Christian Orthodox religion. That is it introduces pupils into one specific religious tradition, namely education into religion according to the typology of Schreiner (2002). A reference to other known religions is made. However, there is no mention on the usefulness of the development of inter-religious dialogue at least in the school context, although the freedom of religious conscience, as it is demonstrated in a European level, is secured/consolidated according to the Greek constitution and the educational legislation. The role, the view and the everyday teaching practice on the subject of RE need to be taken into consideration.

However, the Greek society is not as homogeneous as it used to be in the past and this produces questions regarding the type of education offered and the dimension that should be promoted in the subject of RE. There would be no doubt that the implementation of a monocultural education in the Greek multicultural society would be monolithic and anachronistic, since a curriculum orientated principally towards the Christian Orthodox religion on the one hand would not educate pupils to be tolerant towards people of other religions and faiths, as Zambeta and Coulby (2008) remarkably denotes, and on the other hand would not meet the needs of pupils with other religions or faiths. Besides, school constitutes a micrograph of the world we live in. Therefore, we wonder whether education including RE should be inclusive and take the form of a comparative education which covers a variety of religious systems (Cumper, 2011) so as to depict the existing religious diversity within the Greek society, educate pupils and future citizens in order to manage this diversity and convey the message that each different culture and religion is valued. 


\section{References}

Banks, J., Cookson, P., Gay, G., Howley, W. D., Irvine, J. J., Nieto, S. Schofield, J. W., \& Stephan, W. G. (2001). Diversity within Unity: Essential Principles for Teaching and Learning in a Multicultural Society. Phi Delta Kappan, 83(3), 196-203.

Bash, L. (2008) Faith, Science, and Modernity: Some Issues for Education in the 21st century. In M. Pereyra (Ed.), Changing Knowledge and Education (pp. 123-138). Frankfurt and Main: Peter Lang.

Broome, B. J. (1996). Exploring the Greek Mosaic: a Guide to Intercultural Communication in Greece. Maine/USA: Intercultural Press.

Catalogue on Ecclesiastical schools of Secondary education. (2015). Retrieved July 23, 2015, from http://edu.klimaka.gr/leitoyrgia-sxoleivn/ekklhsiastika/441-katalogos-ekklhsiastikascholeia.html

Circular 12773/42/23-01-2015 of non-attendance of the subject of Religious Education (2015). Retrieved June 24, 2015, from http://edu.klimaka.gr/leitoyrgia-sxoleivn/anakoinvseis/ 884-apallagh-apo-to-mathhma-twn-thrhskevtikwn.html

Coulby, D., \& Zambeta, E. (2008). Intercultural Education, Religion and Modernity. Intercultural Education, 19(4), 293-295. http://dx.doi.org/10.1080/14675980802376812

Council of Europe. (2005). Recommendation 1720/(2005) of the Parliamentary Assembly about Education and Religion. Retrieved June 28, 2015, from http://assembly.coe.int/ Documents/AdoptedText/ta05/EREC1720.htm

Council of Europe. (2008). White Paper on Intercultural Dialogue. Living together as equals in dignity. Retrieved June 28, 2015 http://www.coe.int/t/dg4/intercultural/source/white\%20 paper_final_revised_en.pdf

Council of Europe. (2010). European Convention on Human Rights. Retrieved July 23, 2015, from http://www.echr.coe.int/Documents/Convention_ENG.pdf

Cumper, P. (2011). Religious Education in the European Context in the Twenty -first Centure. In M. Hunter-Henim (Ed.), Law, Religious Freedom and Education in Europe (pp. 207-227). Surrey: Ashgate.

Digital School, Interactive School Textbooks. (2015). Retrieved June 23, 2015, from http://ebooks.edu.gr/new/allmaterial.php

Dreeben, R. (1969). On What is Learned in Schools. Reading and Massachussets: Addison-Wesley.

Efstathiou, I. (2008). Religion in Greek Education in a Time of Globalization. Intercultural Education, 19(4), 325-336. http://dx.doi.org/10.1080/14675980802376853

Frangoudaki, A., \& Dragonas, T. (2000). Intercultural Education in the European Union from a 'Southern' Viewpoint. In J. Gundura, \& S. Jacobs (Eds.), Intercultural Europe: Diversity 
and Social Policy (pp.167-187). Brookfield: Ashgate Publishing Ltd.

Gordon, D. (1982). The Concept of the Hidden Curriculum. Journal of Philosophy of Education, 16(2), 187-198.

Hopkins, D., \& Harris, A. (1997). Improving the Quality of Education for All. Support for Learning, 12(4), 147-151.

Iefimerida. (2016). Muslims in Europe - How many they are, where they live. Retrieved from http://www.iefimerida.gr/news/186711/oi-moysoylmanoi-tis-eyropis-posoi-einai-poy-zoyn-ha rtis

Karamouzis, P. (2014). Religious Capital in Relation to Teachers' Views of RE, A Comparative Study in the Greek Educational Context. British Journal of Religious Education, 37(2), 170-181. http://dx.doi.org/10.1080/01416200.2014.984585

Karamouzis, P. (2014). The Greek Religious Education: From Religion Tradition to Religion Innovation. Journal of Education and Training, 1(2), 321-333. http://dx.doi.org/10.5296/jet. v1i2.5862

Koukounaras-Liagkis, M. (2013). Religious Education in Greek Public Schools in Western Thrace: Identifying Controversial Issues. Mediterranean Journal of Social Studies, 4(11), 274-281. http://dx.doi.org/10.5901/mjss.2013.v4n11p274

Koukounaras-Liagkis, M. (2014). Religious Education in Greece: a New Curriculum, an Old Issue. British Journal of Religious Education, 37(2), 153-169. http://dx.doi.org/10.1080/ 01416200.2014 .944093

Law 1566/1985 Structure and Operation of Primary and Secondary Education and other Regulations. (2015). Retrieved May 24, 2015, from http://www.pi-schools.gr/ preschool_education/nomothesia/1566_85.pdf

Law 3536/2007 (Amendment 16 January 2013). Special regulations on Migration Policy and Other Issues Concerning the Ministry of Interior, Public Administration and Decentralization.

Mousiadou, N. (2014). National Celebrations and Intercultural Education in the Multicultural Greek Kindergarten. PhD Thesis, Department of Early Childhood Education, Aristotle University of Thessaloniki, Greece.

Newpaper of Government 303, $\tau$. B. (2003). Cross-thematic Unified Framework of Studies and the Curricula for Primary Schools and Gymnasium.

OSCE. (2007). The Toledo Guiding Principles on Teaching about Religions and Beliefs in Public Schools. Warsaw: OSCE. Retrieved June 28, 2015 , from http://www.osce.org/node/27217

Palaiologou, N., \& Evaggelou, O. (2015). Cultural Diversity and Educational Policy within the Framework of Greek Primary School. Paper presented at the International Conference of the International Association of Intercultural Education and the University of Ioannina, 
Greece, Ioannina, 29 June - 3July.

Recommendation CM/Rec 12. (2008). On the Dimension of Religions and Non-Religious Convictions within Intercultural education. Retrieved July 26, 2015, from https://wcd.coe.int/ ViewDoc.jsp?id=1386911\&Site $=\mathrm{CM}$

Savvidou, S. (2005). Cultural Polymorphy and Educational Characteristics in the islands of Rhodes - Kos: Forms of Convergence and Reproduction of Cultural Differences in Primary Education. PhD Thesis, Department of Primary Education, University of the Aegean.

Schreiner, P. (2002). Religious Education in the European Context. In L. Broadbent, \& A. Brown (Eds.), Issues in Religious Education (pp. 86-98). London: Routledge Falmer.

The Church of Greece. (1993). Christian denominations and Christian groups. Retrieved October, 2016, from http://www.ecclesia.gr/greek/holysynod/commitees/heresies/omades _christ.html

The Constitution of Greece, (2008). Retrieved June 24, 2015, from http://www.hellenicparliament.gr/UserFiles/f3c70a23-7696-49db-9148-f24dce6a27c8/SYNT AGMA1_1.pdf

Traianou, A. (2009). The Uncertain Character of Recent Educational Reforms in Greece. FORUM, 51(2) 131-142. http://dx.doi.org/10.2304/forum.2009.51.2.131

Tsaliki, E. (2012). Intercultural education in Greece; the Case of Thirteen Primary Schools. $\mathrm{PhD}$ Thesis, Institute of Education, University of London.

Tsekou, A. (2015). The School Textbooks of RE in Secondary Education (1974-2006): a Timeless Research Through the Lens of Peace and Human Rights Education. PhD Thesis, Department of Philosophy and Pedagogy, Aristotle University of Thessaloniki, Greece.

Zambeta, E. (2008). Religion, Modernity and Social Rights in European Education, Intercultural Education, 19(4), 297-304. http://dx.doi.org/10.1080/14675980802376820

\section{Copyright Disclaimer}

Copyright reserved by the author(s).

This article is an open-access article distributed under the terms and conditions of the Creative Commons Attribution license (http://creativecommons.org/licenses/by/3.0/). 